\title{
RESEARCH
}

Open Access

\section{Stand-level biomass models for predicting C stock for the main Spanish pine species}

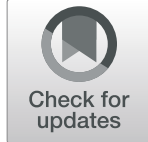

Ana Aguirre ${ }^{1,2^{*}}$ D, Miren del Río ${ }^{2,3}$, Ricardo Ruiz-Peinado ${ }^{2,3}$ and Sonia Condés ${ }^{1}$

\begin{abstract}
Background: National and international institutions periodically demand information on forest indicators that are used for global reporting. Among other aspects, the carbon accumulated in the biomass of forest species must be reported. For this purpose, one of the main sources of data is the National Forest Inventory (NFI), which together with statistical empirical approaches and updating procedures can even allow annual estimates of the requested indicators.

Methods: Stand level biomass models, relating the dry weight of the biomass with the stand volume were developed for the five main pine species in the Iberian Peninsula (Pinus sylvestris, Pinus pinea, Pinus halepensis, Pinus nigra and Pinus pinaster). The dependence of the model on aridity and/or mean tree size was explored, as well as the importance of including the stand form factor to correct model bias. Furthermore, the capability of the models to estimate forest carbon stocks, updated for a given year, was also analysed.

Results: The strong relationship between stand dry weight biomass and stand volume was modulated by the mean tree size, although the effect varied among the five pine species. Site humidity, measured using the Martonne aridity index, increased the biomass for a given volume in the cases of Pinus sylvestris, Pinus halepensis and Pinus nigra. Models that consider both mean tree size and stand form factor were more accurate and less biased than those that do not. The models developed allow carbon stocks in the main Iberian Peninsula pine forests to be estimated at stand level with biases of less than $0.2 \mathrm{Mg}^{\mathrm{ha}} \mathrm{h}^{-1}$.
\end{abstract}

Conclusions: The results of this study reveal the importance of considering variables related with environmental conditions and stand structure when developing stand dry weight biomass models. The described methodology together with the models developed provide a precise tool that can be used for quantifying biomass and carbon stored in the Spanish pine forests in specific years when no field data are available.

Keywords: Martonne aridity index, Dry weight biomass, Carbon stock, National Forest Inventory, Peninsular pine forest, Biomass expansion factor

\footnotetext{
* Correspondence: arnaiz9@hotmail.com

'Department of Natural Systems and Resources, School of Forest Engineering

and Natural Resources, Universidad Politécnica de Madrid, Madrid, Spain

${ }^{2}$ INIA, Forest Research Center, Department of Forest Dynamics and

Management, Madrid, Spain

Full list of author information is available at the end of the article
}

\section{Springer Open}

(c) The Author(s). 2021 Open Access This article is licensed under a Creative Commons Attribution 4.0 International License, which permits use, sharing, adaptation, distribution and reproduction in any medium or format, as long as you give appropriate credit to the original author(s) and the source, provide a link to the Creative Commons licence, and indicate if changes were made. The images or other third party material in this article are included in the article's Creative Commons licence, unless indicated otherwise in a credit line to the material. If material is not included in the article's Creative Commons licence and your intended use is not permitted by statutory regulation or exceeds the permitted use, you will need to obtain permission directly from the copyright holder. To view a copy of this licence, visit http://creativecommons.org/licenses/by/4.0/. 


\section{Background}

Forests are fundamental in the global carbon cycle, which plays a key role in the global greenhouse gas balance (Alberdi 2015), and therefore in climate change. As part of the strategy to mitigate climate change, forest carbon sinks were included in the Kyoto Protocol in 1998 (Breidenich et al. 1998) and subsequent resolutions as the Paris Agreements in 2015. In accordance, countries are requested to estimate forest $\mathrm{CO}_{2}$ emissions and removals as one of the mechanisms for mitigating climate change. Based on the international demands, some international institutions request periodic reports on forest indicators which are used in global reports. For example, the State of Europe's Forest 2015 (SoEF 2015) or Global Forest Resources Assessment 2020 (FRA 2020) request five-yearly information on accumulated carbon in the biomass of woody species or the accumulated carbon in other sources or sinks. Since the development of these international agreements, numerous countries have made efforts to achieve the main objective of mitigating climatic change. In Spain, for example, the Spanish Ministry for Ecological Transition and Demographic Challenge is developing a data base of the national contribution to the European Monitoring and Evaluation Program (EMEP) emission inventory, which includes Land Use, Land-Use Change and Forestry (LULUCF) sector, with the aim of estimating carbon emissions and removals in each land-use category. Furthermore, annually updated greenhouse gas emission data must be provided for the UNFCCC (United Nations Framework Convention on Climate Change) Greenhouse Gas Inventory Data.

Soil and biomass are the most important forest carbon sinks. The carbon present in soils is physically and chemically protected (Davidson and Janssens 2006), although it is more or less stable depending on the type of disturbances suffered and the environmental conditions (Ruiz-Peinado et al. 2013; Achat et al. 2015; BravoOviedo et al. 2015; James and Harrison 2016). Therefore, the carbon that could be returned to the atmosphere from the ecosystem after a disturbance is mainly contained in the aboveground biomass, which accounts for $70 \%-90 \%$ of total forest biomass (Cairns et al. 1997). Carbon stocks and carbon sequestration in tree vegetation are usually estimated thorough biomass evaluation as the amount of carbon in woody species is about $50 \%$ of their dry weight biomass (Kollmann 1959; Houghton et al. 1996). Although species-specific values can be found in the literature, this percentage is recommended by the Intergovernmental Panel on Climate Change (IPCC) if no specific data is available (Eggleston et al. 2006).

There are two main approaches to estimating forest carbon: i) using biogeochemical-mechanisms and ii) the statistical empirical approach (Neumann et al. 2016). The second method is more common in forestry since it uses inventory data such as that provided by NFI's (Tomppo et al. 2010) and the data required does not need to be as specific as for the biogeochemicalmechanism approach. Through this approach, biomass and carbon estimates can be obtained using allometric biomass functions and/or biomass expansion factors (BEFs). Biomass functions require variables for individual trees and/or stand variables (Dahlhausen et al. 2017), while BEFs convert stand volume estimates to stand dry weight biomass (Castedo-Dorado et al. 2012). The BEF method is widely used when little data is available, this being one of the methods recommended in the IPCC guidelines (Penman et al. 2003).

$\mathrm{BEFs}$, including their generalization of stand biomass functions depending on stand volume, can be affected by environmental conditions and stand characteristics, such as the species composition (Lehtonen et al. 2004; Soares and Tomé 2004; Lehtonen et al. 2007; Petersson et al. 2012; Jagodziński et al. 2017). Some authors have also pointed to the dependence of the stand biomass-volume relationship on age or stand development stage (Jalkanen et al. 2005; Peichl and Arain 2007; Tobin and Nieuwenhuis 2007; Teobaldelli et al. 2009; Jagodziński et al. 2017). When age data are not available, as is the case in several NFIs, other variables expressing the development stage can be used as a surrogate of age, such as tree size (Soares and Tomé 2004; Kassa et al. 2017; Jagodziński et al. 2020). In addition, site conditions can influence the relationship between stand biomass and stand volume (Soares and Tomé 2004). These conditions can be assessed by means of indicators such as site index or dominant height (Houghton et al. 2009; Schepaschenko et al. 2018) or directly through certain environmental variables (Briggs and Knapp 1995; Stegen et al. 2011).

Most of the information on forests at national level currently comes from the National Forest Inventories (NFIs). Consequently, many countries have adapted their NFIs to fulfil international requirements (Tomppo et al. 2010; Alberdi et al. 2017). As regards carbon stock, NFIs are widely recognized as being appropriate sources of data for estimating these stocks (Brown 2002; Goodale et al. 2002; Mäkipää et al. 2008), especially at large scales (Fang et al. 1998; Guo et al. 2010). Although most NFIs are carried out periodically, the frequency does not coincide with the international requirements for data on accumulated carbon and biomass stocks (which may be annual). In the case of the Spanish National Forest Inventory (SNFI), the time between two consecutive surveys is longer than that stated in the international requirements for forest statistics reporting. Hence, the forest indicators from SNFI data should be updated annually in order to fulfill the international requirements. 
Moreover, the time between two consecutive SNFI is approximately 10 years, although it is carried out a province at a time, so not all the Spanish forest area is measured in the same year. Whereas other countries measure a percentage of their NFI plots each year, distributed systematically throughout the country (allowing annual national estimates to be made, albeit with greater uncertainly), the approach used in Spain is to measure all the plots within a given province, which does not allow for annual data (or indicators) to be extrapolated at national level. As a consequence, indicators must be updated in the same year for all provinces in order to estimate carbon at national level in a given year. A possible approach to updating carbon stocks indicators from SNFI data would be to estimate the stand biomass through tree allometric biomass functions (Neumann et al. 2016), although this method would require complex individual tree models to update stand information at tree level (tree growth, tree mortality and ingrowth). Given the strong relationship between stand volume and biomass (Fang et al. 1998; Lehtonen et al. 2004), estimations of biomass could be also made by updating volume stocks from the SNFI and using BEFs. This option has the advantage that stand volume can often be easily updated through growth models (Shortt and Burkhart 1996) or even by remote sensing (McRoberts and Tomppo 2007).

According to Montero and Serrada (2013), the main pine species (Pinus sylvestris L., Pinus pinea L., Pinus halepensis Mill., Pinus nigra Arn. and Pinus pinaster Ait.) occupy around of $30 \%$ of the Spanish forest area as dominant species, which is more than 5 million ha, along with almost half a million ha of pine-pine mixtures. Their distribution across the Iberian Peninsula covers a wide range of climatic conditions (Alía et al. 2009), with arid conditions being particularly prominent. Thus, aridity was found to influence the maximum stand density and productivity of these pinewoods (Aguirre et al. 2018, 2019). Furthermore, pine species were those most used in reforestation programs, so these species play a fundamental role in carbon sequestration. According to the Second and Third National Forest Inventories, the five abovementioned species alone account for a carbon stock of around $250 \times 10^{6} \mathrm{Mg} \mathrm{C}$ (del Río et al. 2017), of which more than half corresponds to two of these forest species ( $P$. sylvestris and P. pinaster).

The main objective of this study was to develop dry weight biomass models for pine forests (monospecific and mixed stands) according to stand volume, exploring whether basic BEFs can be improved by including site conditions and stand development stage. We hypothesized that for a given stand volume the stand dry weight biomass increases as site aridity decreases and that it decreases with the stand development stage. Therefore, the specific objectives were to study the dependence of the models on these factors and to assess the biomass expansion factors when varying these variables for the main pine species studied. The biomass models developed will allow carbon estimates to be updated for a given year when no field data from SNFI surveys are available.

\section{Methods \\ Data}

The data used were from two consecutive completed surveys of the SNFI in the Iberian Peninsula, the Second and Third SNFI (SNFI-2 and SNFI-3), which were carried out from 1986 to 1996, and from 1997 to 2007 respectively, except for the provinces of Navarra, Asturias and Cantabria, where the SNFI-2 surveys were carried out using a different methodology. Data from the SNFI3 and SNFI-4 were used for these provinces, covering the periods from 1998 to 2000 and from 2008 to 2010, respectively. The initial and final surveys are referred to regardless of the provinces considered. The time elapsed between surveys ranges from 7 to 13 years depending on the province. Data from the final SNFI surveys were used to develop dry weight biomass estimates, while data from the initial surveys, together with volume growth models by Aguirre et al. (2019), were used to evaluate model assessment capability.

The SNFI consists of permanent plots located systematically at the intersections of a $1-\mathrm{km}$ squared grid in forest areas. The plots are composed of four concentric circular subplots, in which all trees with breast-height diameter of at least 7.5, 12.5, 22.5 and $42.5 \mathrm{~cm}$ are measured in the subplots with radii of $5,10,15$ and $25 \mathrm{~m}$, respectively. Using the appropriate expansion factor for each subplot, stand variables were calculated per species and for the total plot. For further details of the SNFI, see Alberdi et al. (2010).

The target species were five native pine species in the Spanish Iberian Peninsula: Pinus sylvestris (Ps), Pinus pinea (Pp), Pinus halepensis (Ph), Pinus nigra (Pn) and Pinus pinaster $(\mathrm{Pt})$. Plots located in the peninsular pine forests were used; the criterion for selection being that the density of non-target species should not exceed 5\% of the maximum capacity (Aguirre et al. 2018). The plots used for each species were those in which the proportion of the species by area was greater than 0.1. Additionally, to allow the application of the results to stands where the volume was updated through growth models, only those plots in which silvicultural fellings affected less than $5 \%$ of the total basal area were considered, as this was the criterion used for developing the existing volume growth models (Aguirre et al. 2019). 
Stem volume was calculated for every tree in the plot according to SNFI volume equations developed for each province, species and stem form (Villanueva 2005). The Martin (1982) criteria were used to obtain volume growth. Dry weight biomass for different tree components was calculated at tree level using equations taken from Ruiz-Peinado et al. (2011), who developed biomass models for all the studied species, using diameter at breast height and total tree height as independent variables. Total tree aboveground dry weight biomass was calculated by adding the weight of stem (stem fraction), thick branches (diameter larger than $7 \mathrm{~cm}$ ), medium branches (diameter between 2 and $7 \mathrm{~cm}$ ) and thin branches with needles (diameter smaller than $2 \mathrm{~cm}$ ). Based on tree data and using the appropriate expansion factors for each SNFI subplot, the stand level volume and dry weight biomass were obtained per species and total plot.

To estimate the aridity conditions for each plot used, the annual precipitation $(P$, in $\mathrm{mm})$ and the mean annual temperature $\left(\mathrm{Tm}\right.$, in $\left.{ }^{\circ} \mathrm{C}\right)$ were obtained from raster maps with a one-kilometer resolution developed by Gonzalo Jiménez (2010). These variables were used to obtain the
Martonne aridity index (De Martonne 1926), $M$, calculated as $M=P /(T m+10)$, in $m m \cdot{ }^{\circ} \mathrm{C}^{-1} \cdot M$ was chosen as an aridity indicator because of its simplicity and recognized influence on volume growth (Vicente-Serrano et al. 2006; Führer et al. 2011; Aguirre et al. 2019) and maximum stand density (Aguirre et al. 2018). Hence, $M$ was expected to have a positive influence on dry weight biomass.

Due to the lack of age information for SNFI plots, the development stage had to be estimated through specific indicators. Tree-size related variables are commonly used as surrogates for stand development stage, one such variable being the mean tree volume $(v m)$, which could be used to correct the lack of age information. The $v m$ was calculated as in Eq. 1 , where $V$ is the volume of the stand in $\mathrm{m}^{3} \cdot \mathrm{ha}^{-1}$ and $N$ is the number of the trees per hectare, both referred to the target species $(s p)$.

$$
v m_{s p}=\frac{V_{s p}}{N_{s p}}
$$

A summary of the data used to develop the models is shown in Table 1 (note that when a target species was

Table 1 Summary of data used to develop dry weight biomass models. Note that plots where a target species, $s p$, is studied, other pine species could be present

\begin{tabular}{|c|c|c|c|c|c|c|c|c|c|c|c|c|c|c|}
\hline \multirow[t]{2}{*}{$s p$} & & \multicolumn{6}{|c|}{ Initial SNFI survey } & \multicolumn{7}{|c|}{ Final SNFI survey } \\
\hline & & $N_{s p \_l}$ & $N_{l}$ & $V_{s p \_l}$ & $V_{l}$ & $W_{s p \_l}$ & $\overline{f_{s p \_l}}$ & $N_{s p \_} F$ & $N_{F}$ & $V_{s p_{-} F}$ & $V_{F}$ & $W_{s p_{-} F}$ & $f_{s p \_F}$ & $M$ \\
\hline \multirow{4}{*}{$\begin{array}{l}\text { Ps } \\
(\# 1854)\end{array}$} & Mean & 753 & 846 & 109.7 & 121.9 & 109.7 & 0.51 & 794 & 909 & 159.2 & 178.3 & 147.3 & 0.50 & 51 \\
\hline & sd & 544 & 560 & 91.6 & 90.8 & 69.1 & 0.07 & 570 & 588 & 108.5 & 104.1 & 80.6 & 0.06 & 14 \\
\hline & Min & 14 & 46 & 3.0 & 17.1 & 5.1 & 0.35 & 14 & 56 & 5.8 & 26.3 & 8.0 & 0.37 & 23 \\
\hline & Max & 3692 & 4106 & 747.4 & 747.4 & 520.3 & 1.11 & 4297 & 4311 & 826.8 & 843.2 & 574.5 & 0.93 & 118 \\
\hline \multirow{4}{*}{$\begin{array}{l}\text { Pp } \\
\text { (\# 537) }\end{array}$} & Mean & 337 & 386 & 51.5 & 59.4 & 66.8 & 0.51 & 348 & 405 & 76.1 & 88.3 & 92.7 & 0.48 & 24 \\
\hline & $\mathrm{sd}$ & 357 & 376 & 38.6 & 39.1 & 40.2 & 0.14 & 369 & 387 & 49.8 & 50.1 & 50.6 & 0.1 & 5 \\
\hline & Min & 5 & 20 & 1.7 & 11.8 & 3.6 & 0.18 & 5 & 31 & 2.0 & 17.1 & 3.8 & 0.23 & 12 \\
\hline & Max & 3102 & 3197 & 350.4 & 350.4 & 335.4 & 1.65 & 3233 & 3233 & 406.0 & 406.0 & 392.3 & 1.24 & 45 \\
\hline \multirow{4}{*}{$\begin{array}{l}\mathrm{Ph} \\
(\# 2 \text { 2039) }\end{array}$} & Mean & 491 & 516 & 37.3 & 39.5 & 37.4 & 0.52 & 546 & 579 & 56.9 & 60.3 & 57.6 & 0.48 & 21 \\
\hline & $\mathrm{sd}$ & 348 & 352 & 24.5 & 25.3 & 23.0 & 0.14 & 377 & 381 & 35.5 & 36.8 & 33.5 & 0.09 & 6 \\
\hline & Min & 5 & 25 & 2.8 & 4.8 & 2.6 & 0.29 & 5 & 25 & 3.3 & 7.5 & 3.2 & 0.21 & 7 \\
\hline & Max & 2465 & 3006 & 238.2 & 241.4 & 194.6 & 1.84 & 2451 & 2798 & 283.0 & 287.6 & 242.9 & 1.18 & 52 \\
\hline \multirow{4}{*}{$\begin{array}{l}\text { Pn } \\
(\# 1414)\end{array}$} & Mean & 703 & 837 & 75.8 & 90.6 & 83.8 & 0.54 & 749 & 909 & 111.1 & 133.5 & 117.2 & 0.53 & 38 \\
\hline & $\mathrm{sd}$ & 586 & 604 & 61.8 & 62.5 & 59.6 & 0.09 & 615 & 629 & 78.9 & 77.2 & 74.1 & 0.07 & 10 \\
\hline & Min & 10 & 41 & 1.4 & 17.8 & 2.7 & 0.35 & 10 & 41 & 2.3 & 22.5 & 4.0 & 0.29 & 20 \\
\hline & Max & 4994 & 4994 & 522.8 & 522.8 & 451.7 & 1.22 & 4623 & 4623 & 577.4 & 577.4 & 552.4 & 1.65 & 105 \\
\hline \multirow{4}{*}{$\begin{array}{l}\text { Pt } \\
(\# 1358)\end{array}$} & Mean & 532 & 604 & 94.8 & 103.5 & 71.3 & 0.51 & 550 & 640 & 149.5 & 163.1 & 108.6 & 0.49 & 33 \\
\hline & $\mathrm{sd}$ & 443 & 466 & 64.8 & 66.5 & 44.1 & 0.07 & 443 & 472 & 88.8 & 87.8 & 57.7 & 0.06 & 12 \\
\hline & Min & 10 & 51 & 1.4 & 19.3 & 1.2 & 0.33 & 10 & 40 & 6.2 & 30.8 & 5.5 & 0.35 & 17 \\
\hline & Max & 3310 & 3310 & 515.6 & 562.5 & 332.8 & 0.89 & 2886 & 2886 & 652.4 & 652.4 & 475.3 & 0.91 & 87 \\
\hline
\end{tabular}

$N$, is the total number of trees per hectare while $N_{s p}$ represents the number of trees of the main species; $V$, is the total volume and $V_{s p}$ main species volume, both in $\mathrm{m}^{3} \cdot \mathrm{ha}^{-1} ; W_{s p}$ is the main species dry weight of biomass in $\mathrm{Mg} \cdot \mathrm{ha}^{-1} ; f_{s p}$, is the species stand form factor, calculated as in Eq. 5 ; and $M$ is the Martonne aridity index in $\mathrm{mm} \cdot{ }^{\circ} \mathrm{C}^{-1}$. The subscript "l" refers to initial survey and " $\mathrm{F}$ " to final survey. Ps Pinus sylvestris, Pp P. pinea, Ph P. halepensis, Pn P. nigra, and Pt P. pinaster. The number of plots used to develop models is shown under the name of the target species (\#) 
studied, other pine species could be included within stands). Figure 1 summarizes the methodology that is described in the following sections.

\section{Biomass estimation models by species}

Basic biomass models were developed for each species from $\mathrm{SNFI}_{\mathrm{F}}$ data in accordance with the structure used by Lehtonen et al. (2004) (Eq. 2) to estimate dry weight biomass $(W)$ from stand volume $(V)$ for the target species. The Basic Model was modified by including the effect of aridity, thus, the Martonne aridity index $(M)$ was added to the Basic Model to obtain the so-called Basic M Model (Eq. 3). As regards the model structure, following a preliminary study (not shown) it was decided to include the logarithm of this variable to adapt the Basic Model (Eq. 2), modifying the ' $a$ ' coefficient according to Eq. 3.

$$
\begin{aligned}
& \text { Basic Model : } W_{j k}=\left(a+a_{k}\right) \times V_{j k}^{b}+\varepsilon_{j k} \\
& \qquad \begin{aligned}
\text { Basic M Model : } W_{j k}= & \left(a+a_{k}\right) \times V_{j k}^{b} \\
& \times\left(1+m \times \log \left(M_{j k}\right)\right) \\
& +\varepsilon_{j k}
\end{aligned}
\end{aligned}
$$

where, for plot $j$ in province $k, W$ is the dry weight biomass of the target species in $\mathrm{Mg}^{-} \mathrm{ha}^{-1}, V$ is the volume of the target species in $\mathrm{m}^{3} \cdot \mathrm{ha}^{-1}, M$ is the Martonne aridity index, in $\mathrm{mm} \cdot{ }^{\circ} \mathrm{C}^{-1}$; and $\varepsilon$ is the model error. The coefficient $a$ is the fixed effect, while $a_{k}$ is the province random effect to avoid possible correlation between plots belonging to the same province, as the measurements in the different provinces were carried out in different years and by different teams. $b$ and $m$ are other coefficients to be estimated: if coefficient $m$ was not significant for a given species or its inclusion did not improve the Basic Model, $M$ was no longer included in the species model.

To determine how the stand development stage influences the relationships between volume and dry weight biomass for each species, the mean tree volume $(\mathrm{vm})$ was included in the models. This variable also multiplies the coefficient ' $\left(a+a_{k}\right)$ ' (Eq. 4$)$, so that if it was not significant, the final model will be equivalent to the basic one.

$$
\begin{aligned}
\nu m \text { Model : } W_{j k}= & \left(a+a_{k}\right) \times V_{j k}^{b} \\
& \times(1+m \times \log (M)) \\
& \times\left(1+c_{1} \times v m_{j k}^{p_{1}}\right)+\varepsilon_{j k}
\end{aligned}
$$

where, $a, a_{k}, b, c_{1}, p_{1}$ and $m$ were the coefficients to be estimated and $v m$ is the mean tree volume, all variables referring to the target species.

When fitting the biomass models some bias linked to the stem form was detected. Hence, the next step was to test whether it was possible to correct the model bias by adding the shape of the trees by means of the stand form factor $(f)$ (Eq. 5). This variable was also added to multiply the coefficient ' $\left(a+a_{k}\right)$ ', thus obtaining the Total Model (Eq. 6).

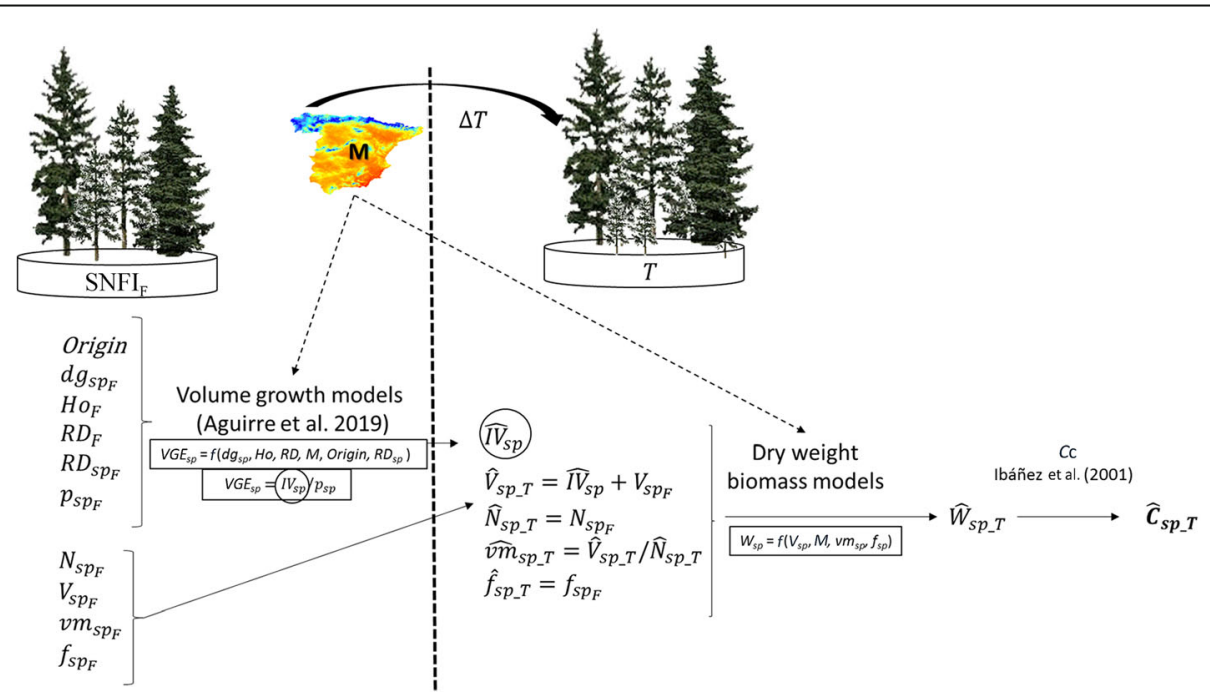

Fig. 1 Schematic explanation about how to apply the developed model for future projections. SNFI is the last Spanish National Forest Inventory available, $\Delta T$ is the time elapsed between $S_{N F F}$ and the projection time $T, M$ is the Martonne aridity index, Origin is the naturalness of the stand (plantation or natural stand), $d g$ is the quadratic mean diameter $(\mathrm{cm}), H o$ is the dominant height $(\mathrm{m}), R D$ is the relative stand density, $p$ is the proportion of basal area of the species in the stand, $V G E$ is the volume growth efficiency, $I V$ is the volume increment $\left(\mathrm{m}^{3} \cdot \mathrm{ha}^{-1} \cdot \mathrm{year}^{-1}\right), N$ is the number of trees per hectare, $V$ is the volume of the stand $\left(\mathrm{m}^{3} \cdot h \mathrm{a}^{-1}\right), v m$ is the mean tree volume, $f$ is the stand form factor, $W$ is the dry weight biomass, and $C$ is the weight of carbon. The subscript " $F$ " refers to the final SNFI, the last available, while "T" refers at projection time $T$. The variables with the subscript "sp" refer to the target species, variables without the subscript refer to the stand 


$$
f=\frac{V}{G \times H}
$$

where $f$ is the stand form factor; $V$ is the stand volume $\left(\mathrm{m}^{3} \cdot \mathrm{ha}^{-1}\right) ; G$ is the basal area $\left(\mathrm{m}^{2} \cdot \mathrm{ha}^{-1}\right)$; and $H$ is the mean height of the plot $(\mathrm{m})$, all variables referring to the target species.

$$
\text { Total Model : } \quad \begin{aligned}
W_{j k}= & \left(a+a_{k}\right) \times V_{j k}^{b} \\
& \times(1+m \times \log (M)) \\
& \times\left(1+c_{1} \times v m_{j k}^{p_{1}}\right) \\
& \times\left(1+c_{2} \times f_{j k}^{p_{2}}\right)+\varepsilon_{j k} .
\end{aligned}
$$

where $a, a_{k}, b, c_{1}, c_{2}, p_{1}, p_{2}$ and $m$ were the coefficients to be estimated, $f$ is the form factor of the stand and $v m$ is the mean tree volume, all variables referring to the target species.

The model structure was analysed in a preliminary study where each coefficient in the allometric basic model was parametrized in function of $M, v m$ and $f$, considering linear and non-linear expansions. The final model structure (Eq. 6) was selected because its better goodness of fit in terms of AIC, showing also the lowest residuals.

All models (Eqs. 2 to 4 and Eq. 6) were fitted using non-linear models with the nlme package (Pinheiro et al. 2017) from the R software (Team RC 2014). The coefficients were only included if they were statistically significant ( $p$-value $<0.05)$ and their inclusion improved the model in terms of Akaike Information Criterion (AIC) (Akaike 1974). Furthermore, conditional and marginal $R^{2}$ (Cox and Snell 1989; Magee 1990; Nagelkerke 1991) were calculated as a goodness-of-fit statistic using MuMIn library (Barton 2020). Once selected the model with the lowest AIC, and highest marginal and conditional $R^{2}$, and to check that the improvement achieved is significant, anova tests were made.

\section{Evaluation of biomass estimation models}

In order to evaluate the goodness of fit, an analysis of the four developed models (Eqs. 2 to 4 and Eq. 6) was performed. The mean errors (Eqs. 7 to 9), estimated in

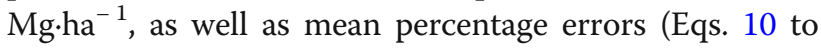
12 ) in \% were calculated for each model of each species.

$$
\begin{aligned}
& \text { Mean error }: \mathrm{ME}=\sum e_{j} / n \\
& \text { Mean absolute error }: \mathrm{MAE}=\sum\left|e_{j}\right| / n \\
& \text { Root mean square error RMSE }=\sqrt{\sum e_{j}^{2} / n}
\end{aligned}
$$

Mean percentage error : MPE

$$
=100 \times \sum e p_{j} / n
$$

Mean absolute percentage error : MAPE

$$
=100 \times \sum\left|e p_{j}\right| / n
$$

Root mean square percentage error : RMSPE

$$
=100 \times \sqrt{\sum e p_{j}^{2} / n}
$$

where $e_{j}=W_{j}-\widehat{W}_{j}$ and $e p_{j}=\left(W_{j}-\widehat{W}_{j}\right) / W_{j} ; \widehat{W}_{j}$ is the estimated values of dry weight biomass for each plot $j, W_{j}$ the corresponding observed values for each plot $j$, both referring to the target species; and $n$ is the number of plots where the species was present.

\section{Carbon predictions at national level}

The models developed (Eqs. 4 to 6 and Eq. 8) provide estimates of dry weight biomass per species, both in monospecific and mixed stands, which could be transformed to carbon stock, considering the specific data of carbon content in wood given by Ibáñez et al. (2002) for the five studied pine species (Table 2).

To evaluate the prediction capacity of the fitted models at time $T$ when no field data is available, a simulation from the initial SNFI survey $\left(\mathrm{SNFI}_{\mathrm{I}}\right)$ was performed at a national scale, assuming that this was the last available survey.

The first step was to obtain the predicted biomass at time $T$, where all variables are supposed to be unknown for each species, from the four biomass models developed (Eqs. 2 to 4 and Eq. 6). To apply these models, it was necessary to obtain the values of all independent variables, updated to year $T$. This procedure was done as follow:

- Using the annual growth volume models by Aguirre et al. (2019), the volume $\hat{V}_{T}$ was estimated from the $\mathrm{SNFI}_{\mathrm{I}}$ volume. These authors developed a volume growth efficiency (VGE) model for the five pine species considered in this study. Volume growth efficiency is a measure of stand volume growth taking into account the species proportions by area

Table 2 Carbon content of wood for the studied species (Ibáñez et al. 2002)

\begin{tabular}{ll}
\hline Species & Carbon content (\%) \\
\hline Pinus sylvestris & 50.9 \\
Pinus pinea & 50.8 \\
Pinus halepensis & 49.9 \\
Pinus nigra & 50.9 \\
Pinus pinaster & 51.1 \\
\hline
\end{tabular}


$(p)$, which is necessary when studying mixed stands

(Condés et al. 2013), as $V G E=I V / p$. In monospecific stands $V G E=I V$. So, with these estimations $(I V)$ and the number of years elapsed since initial SNFI $(\Delta T)$, the volume at time $T$ was estimated as $\hat{V}_{T}=V_{I}$ $+I V \times \Delta T$.

- The mean tree volume $\widehat{v m}_{T}$ was estimated assuming that there are no extractions or high mortality in plots during $\Delta T$, that is, assuming the number of trees per hectare remains constant $\left(\hat{N}_{T}=N_{I}\right)$, so that, $\widehat{v m}_{T}=\hat{V}_{T} / \hat{N}_{T}$.

- Furthermore, it was assumed that the stand form factor does not vary significantly in the time elapsed between inventories, so this variable was estimated as $\hat{f}_{T}=f_{I}$.

As the predictions were made for the same plots used to develop the growth models by Aguirre et al. (2019), biomass models can be applied directly, without the need to perform calibrations, since the fixed and random effects are known. Hence, by applying the different models (Eqs. 2 to 4 and Eq. 6) and using the independent variables described $\left(\hat{V}_{T}, \widehat{v m}_{T}\right.$ and $\left.\hat{f}_{T}\right)$, we obtain the biomass estimated at time $T\left(\hat{W}_{T}\right)$, which is assumed to be unknown.

Secondly, using the carbon percentages contained in the biomass weight shown in Table 2, the carbon weight estimated for each species was obtained at time $T\left(\hat{C}_{T \_s p}\right.$

). Considering all species present in each plot, the total carbon weight was estimated at time $T\left(\hat{C}_{T}=\sum \hat{C}_{T \_s p}\right)$.

Finally, in order to evaluate the predictions, time $T$ was set to be the same as the final SNFI $\left(\mathrm{SNFI}_{\mathrm{F}}\right)$, therefore the observed values were already known and could be compared with the predictions obtained. Thus, the predicted carbon $\left(\hat{C}_{T}\right)$ was compared with the observed carbon weight for the final SNFI $\left(C_{F}\right)$, obtained by multiplying the observed dry weight biomass (as explained in the data section) and the carbon content (Table 2) in the final survey $\left(\mathrm{SNFI}_{\mathrm{F}}\right)$. The mean errors were then calculated from Eqs. 9 to 14 .

\section{How to estimate carbon stocks at national level when no data is available}

In this section, it is explained how to apply the developed models for predicting the carbon stock at time $T$ required, when no data is available. For this, it is necessary to use some variables of the last Spanish National Forest Inventory available $\left(\mathrm{SNFI}_{\mathrm{F}}\right), \Delta T$ years before $T$.

The first step is to estimate the volume growth efficiency of the target species $\left(V G E_{s p}\right)$, which can be estimated using Aguirre et al. (2019) models. These models estimate $V G E$ as function on:
- Origin, makes reference to the naturalness of the stand. It was a dummy variable, with value 1 when the stand was a plantation and 0 when the stand comes from natural regeneration.

- $d g_{s p}$, is the quadratic mean diameter of the target species.

- Ho, is the dominant height of the stand.

- $R D$, is the relative stand density (Aguirre et al. 2018, Eq. S1), and $R D_{s p}$ is only considering the target species.

$-p_{s p}$, is the proportion of the species.

- $M$, is the Martonne aridity index.

With these variables it is possible to estimate $V G E_{s p}$ for each pine species considered, and using its proportion, also volume growth of each species $\left(I V_{s p}\right)$ can be estimated. Note that in monospecific stands $I V_{s p}$ is equal to $I V$ total.

Having the $I V_{s p}$, the time elapsed since $T$ and $\mathrm{SNFI}_{\mathrm{F}}$ and the volume of the target species at $\operatorname{SNFI}_{\mathrm{F}}\left(V_{s p F}\right)$ the volume at $T$ time is estimated $\left(\hat{V}_{s p_{-} T}\right)$.

Obtained $\hat{V}_{s p_{-} T}$, the biomass models can be applied by using some assumptions:

- The number of trees per hectare remains constant at equal to the observed in $\operatorname{SNFI}_{\mathrm{F}}\left(\hat{N}_{s p_{-} T}=N_{s p F}\right)$.

- So, the mean tree volume at time $T$ can be estimated as: $\widehat{v m}_{s p_{-} T}=\hat{V}_{s p_{-} T} / \hat{N}_{s p_{-} T}$.

- The stand form factor also is considered constant at equal to the observed in $\left.\operatorname{SNFI}_{\mathrm{F}} \widehat{(f}_{s p_{-} T}=f_{s p F}\right)$.

Using these estimated variables, biomass models can be used to obtain the estimation of dry weight biomass of the target species at time $T\left(\hat{W}_{s p_{-} T}\right)$. The appropriate percentage of the carbon content per species (Ibáñez et al. 2002) allows to transform that value in the estimated carbon of the target species at time $T\left(\hat{C}_{s p_{-} T}\right)$. For mixed stands, the estimated carbon of the stand $(\hat{C})$ is the sum of the different $\hat{C}_{s p_{-} T}$.

\section{Results}

\section{Biomass estimation models for each species}

Table 3 shows the coefficient estimates together with the standard errors and goodness of fit for the four models developed for dry weight biomass of the five species studied (Eqs. 2 to 4 and Eq. 6). When the Basic Model (Eq.2) was compared with the Basic M Model (Eq. 3) it was observed that aridity $(M)$ was significant in three of the five species and in all three cases it resulted in an improvement in the Basic Model, both in terms of AIC and marginal and conditional $R^{2}$. The species for which $M$ was not significant in the models were $\mathrm{Pt}$ and 


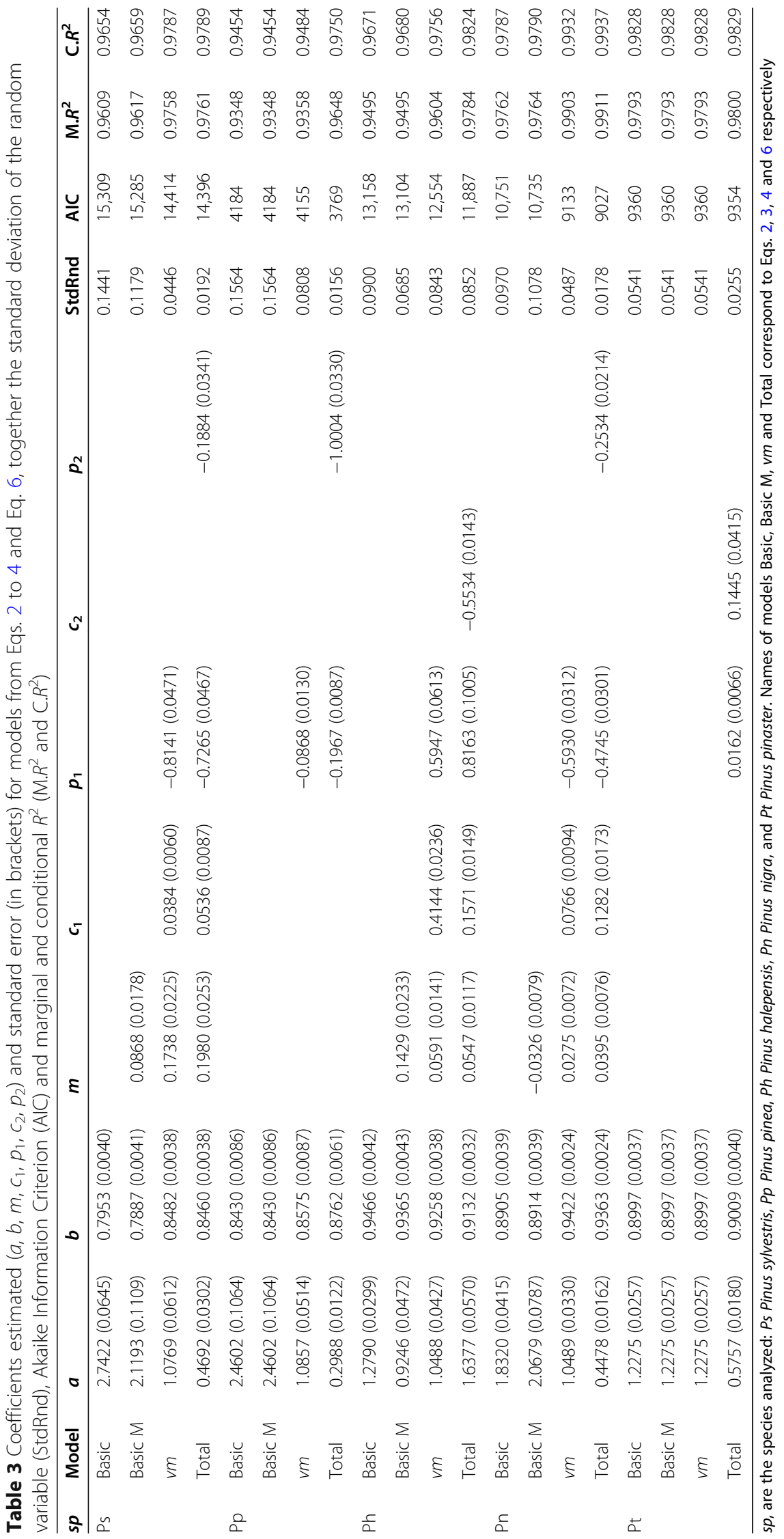


Pp. Among the species for which $M$ was significant, Ps and $\mathrm{Ph}$ showed the greatest increase in conditional and marginal $R^{2}$, while a slightly negative effect was only detected in the case of Pn (Table 3).

The estimates obtained for the coefficients $c_{1}$ and $p_{1}$ in the models that include $v m$ indicate the high importance of this variable for estimating biomass weight. Nevertheless, its influence was less in the case of $\mathrm{Pt}$, as reflected by its low $p_{1}$ value (Fig. 2c, Table 3 ). The coefficients can be significant either as exponents or by multiplying the variables, or in both ways.

The bias observed when fitting the models was corrected by including the stand form factor $f$. When the Total Model and vm Model were compared, the bias correction was more clearly observed in the Ph model, while for Ps and Pt the inclusion of $f$ only had a slight effect (Table 3).

When the estimation errors were analyzed using the different models (Table 4) it was observed that the bias was always less than $0.2 \mathrm{Mg} \cdot \mathrm{ha}^{-1}$, which in relative terms is equivalent to less than $3 \%$. In general, the models overestimated the biomass weight (negative ME), although for $\mathrm{Ph}$ and $\mathrm{Pp}$ all the fitted models overestimated the biomass, except the Total Model for Pp. In addition, Pn and Pp were the species for which the greatest reduction in RMSE was observed, comparing the Total Model and Basic Model (greater than 4.5\%), while this reduction was the lowest for $\mathrm{Pt}$ (around $0.06 \%$ ).

Having selected the Total Model as the best model to estimate the dry weight biomass for all species, the influence of each independent variable was analyzed. In Fig. 2, the variation of dry weight biomass with each variable was presented, assuming the rest of the variables not represented on the axis remain constant. Figure 2a shows a clear positive relationship between dry weight biomass and stand volume, with Pp being the species producing the highest stand biomass for a given volume, although it was very similar to $\mathrm{Ph}$ and $\mathrm{Pn}$. If stand volume $(V)$ is considered constant, it is possible to analyze the variation in $W$ with aridity (Fig. 2b), observing that for all species where $M$ was included in the model (Ps, $\mathrm{Ph}$ and $\mathrm{Pn}$ ) the relationship was positive, that is, the higher the $M$ value (less aridity), the higher the $W$ value for a given $V$.
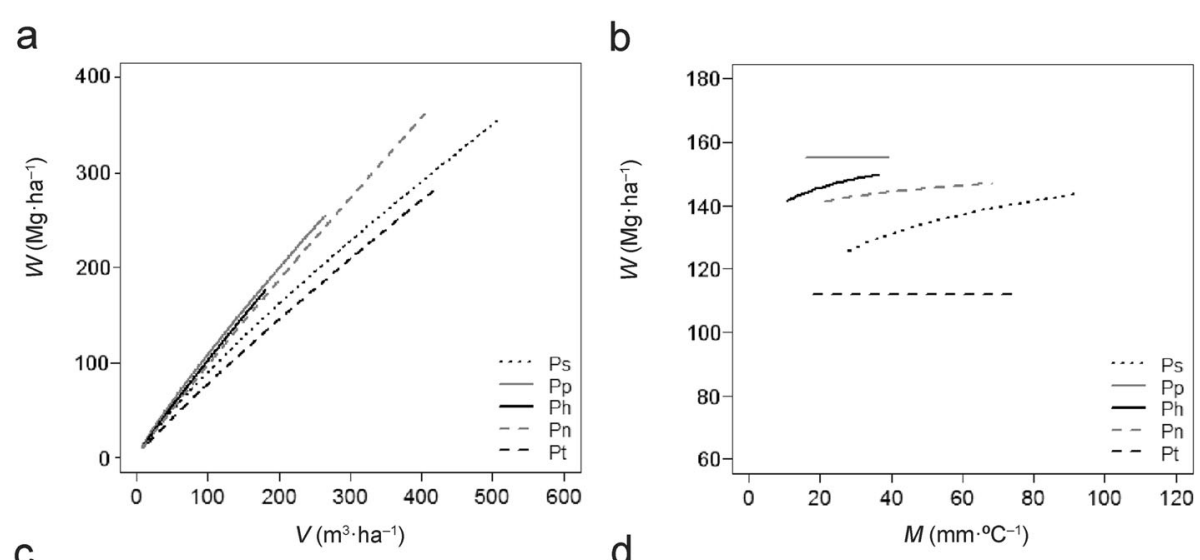

C

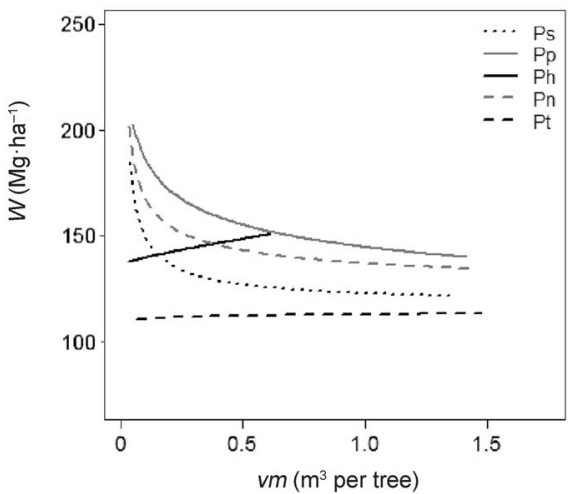

d

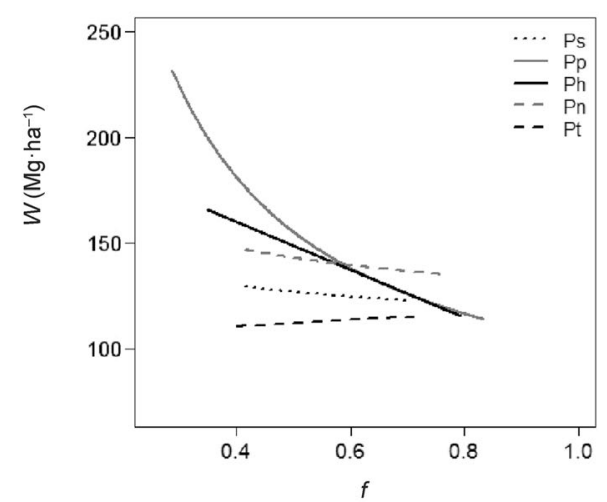

Fig. 2 The selected model (Total Model), showing the dry weight biomass estimations for the target species $\left(W\right.$, in $\left.M g \cdot h a^{-1}\right)$ according to: a volume of the stand for the target species $\left(V\right.$, in $\left.\mathrm{m}^{3} \cdot \mathrm{ha}^{-1}\right)$; b Martonne aridity index $\left(M\right.$, in $\left.\mathrm{mm} \cdot{ }^{\circ} \mathrm{C}^{-1}\right)$; c mean tree volume $\left(\mathrm{vm}\right.$, in $\mathrm{m}^{3}$ per tree); and $\mathbf{d}$ stand form factor $(f)$. The variable represented in each figure on the $x$ axis, ranges from $1 \%$ to $99 \%$ of its distribution in the data used, while the rest of the variables remain constant and equal to: $V=150 \mathrm{~m}^{3} \cdot \mathrm{ha}^{-1} ; M=30 \mathrm{~mm} \cdot{ }^{\circ} \mathrm{C}^{-1} ; f=0.5$; and $v \mathrm{~m}=0.5 \mathrm{~m}^{3}$ per tree. Species as in Table 3 
Table 4 Model errors calculated through Eqs. 7 to 12

\begin{tabular}{llllllll}
\hline sp & Model & ME & MAE & RMSE & MPE & MAPE & RMSPE \\
\hline Ps & Basic & -0.026 & 11.280 & 14.592 & -2.903 & 10.641 & 15.843 \\
& Basic M & -0.010 & 11.183 & 14.477 & -2.847 & 10.583 & 15.774 \\
& $v m$ & -0.039 & 8.711 & 11.444 & -1.930 & 7.935 & 11.626 \\
& Total & -0.046 & 8.679 & 11.384 & -1.955 & 7.930 & 11.631 \\
Pp & Basic & 0.198 & 7.950 & 11.198 & -2.173 & 10.916 & 15.593 \\
& Basic M & 0.198 & 7.950 & 11.198 & -2.173 & 10.916 & 15.593 \\
& vm & 0.199 & 7.468 & 10.794 & -1.894 & 10.135 & 14.625 \\
& Total & -0.013 & 5.629 & 7.520 & -1.919 & 7.695 & 11.066 \\
Ph & Basic & 0.064 & 3.899 & 5.922 & -0.640 & 7.244 & 10.206 \\
& Basic M & 0.077 & 3.845 & 5.836 & -0.517 & 7.208 & 10.118 \\
& vm & 0.095 & 3.609 & 5.082 & -0.383 & 7.182 & 9.865 \\
& Total & 0.059 & 3.246 & 4.327 & -0.374 & 6.456 & 8.388 \\
Pn & Basic & -0.166 & 7.564 & 10.430 & -2.108 & 7.964 & 10.803 \\
& Basic M & -0.173 & 7.511 & 10.364 & -2.108 & 7.892 & 10.670 \\
& $v m$ & -0.037 & 3.956 & 5.820 & -0.783 & 4.249 & 6.254 \\
& Total & -0.078 & 3.867 & 5.615 & -0.949 & 4.224 & 6.110 \\
Pt & Basic & -0.018 & 4.993 & 7.240 & -1.002 & 5.244 & 7.278 \\
& Basic M & -0.018 & 4.993 & 7.240 & -1.002 & 5.244 & 7.278 \\
& $v m$ & -0.018 & 4.993 & 7.240 & -1.002 & 5.244 & 7.278 \\
& Total & -0.012 & 4.988 & 7.210 & -0.965 & 5.224 & 7.219 \\
\hline
\end{tabular}

$s p$, species as in Table 3. Model, names of models, Basic, Basic M, vm and Total correspond to Eqs. 4, 5, 6 and 8 respectively. $M E$ mean error $\left(\mathrm{Mg} \cdot \mathrm{ha}^{-1}\right)$, MAE mean absolute error $\left(\mathrm{Mg}^{\prime} \cdot \mathrm{ha}^{-1}\right)$, RMSE Root mean square error $\left(\mathrm{Mg}^{-} \mathrm{ha}^{-1}\right), \mathrm{MPE}$ mean percentage error (\%), MAPE mean absolute percentage error (\%), RMSE Root mean square percentage error (\%)

Furthermore, the effect of aridity on this biomass-volume relationship varied according to the species, with Ps being the species for which this influence was the greatest (Fig. $2 \mathrm{~b}$, Table 3). Analyzing the dry weight biomass variation according to $v m$ (Fig. 2c), it was observed that the tendency of the relationship between $W$ and $v m$ was similar for $\mathrm{Pp}, \mathrm{Pn}$ and $\mathrm{Ps}$, that is, the higher the mean tree volume, the lower the $W$ estimated for a given $V$. An increase in $v m$, for a constant $V$, indicates that the stand is composed of a smaller number of larger trees whereas a decrease in $v m$ indicates that the same stand volume comprising a greater number of smaller trees. Figure 2c shows that the $v m$ effect is more evident when trees are smaller, while the relationship tends to be more constant as the size of trees increases. Note that for Pt and Ph, the $v m$ effect was opposite to that for the other studied species, that is, positive. Figure 2c shows this effect clearly for $\mathrm{Ph}$, despite being the species with the lowest range of $\mathrm{vm}$ variation, while for $\mathrm{Pt}$, the influence of $v m$ was only slight, despite being one of the species with the highest range of variation of this variable. As regards the stand form factor $(f)$, in general, $W$ decreased as $f$ approached the unit value (Fig. 2d), although in the case of Pt there is a very slight positive effect of $f$. The influence of $f$ on $W$ was not decisive for Ps and Pn, while it was especially important for $\mathrm{Pp}$ and $\mathrm{Ph}$.

\section{Biomass expansion factors}

According to the fitted models, the BEF, i.e. stand biomass weight/stand volume, is not constant but rather decreases as the stand volume increases. Figure 3 represents the species BEF variation within the interpercentile 5\%-95\% range of the species stand volume in monospecific stands for the mean and the extreme values of each of the independent variables in the Total Model. For all species, the estimated BEF values generally varied between 0.5 and $1.5 \mathrm{Mg} \cdot \mathrm{m}^{-3}$, and the lowest estimations were found for Pt, for which the BEF values were almost constant and around to $0.75 \mathrm{Mg} \cdot \mathrm{m}^{-3}$. In contrast, the species for which the highest BEF was obtained was Pp, when $f$ or $v m$ had lower values. BEF estimations for this species could reach values of more than $1.5 \mathrm{Mg} \cdot \mathrm{m}^{-3}$ for low stand volume.

Figure 3 shows that the BEF of Pt was always lower than 0.9 and was not influenced by $M$ and hardly affected by $v m$ or $f$. The BEF values presented little variation in the $M$ range distribution for any of the pine species studied, despite being a statistically significant variable. However, it can be seen in Fig. 3 that Ps was the species most affected by aridity. In contrast, the BEF variation for different $v m$ values was evident (Fig. 3), being the variable that produced the most change in BEFs for Ps and Pn, although it also affected Pp. Highly variable BEFs values can be observed for $\mathrm{Pp}$ and $\mathrm{Ph}$ within the $f$ range distribution of the species, while for Ps and Pt this relationship was practically insignificant. If the different species are compared, Pn shows more constant BEF values than the other species, regardless of stand volume.

\section{Carbon predictions at national level}

The results confirmed that the Total Model was also that which gave the lowest bias when carbon predictions were update to time $T$ in the pine stands across peninsular Spain (Fig. 4). This model allowed carbon estimates with lower errors, both in absolute and relative terms, than the rest of the models, despite all the assumptions described, that is, constant values for both the number of trees per hectare and stand form factor in the elapsed interval considered.

In Fig. 4, it can be seen that all models produced overestimations of carbon stocks, except the Total Model, which produced the lowest bias, although it slightly underestimated carbon stock. Figure 4 also shows that the inclusion of the $f$ variable scarcely modified the errors (MAE, RMSE, MAPE and RMSPE), although the bias decreased significantly. When the Total Model was used, the RMSE obtained when making carbon stock 

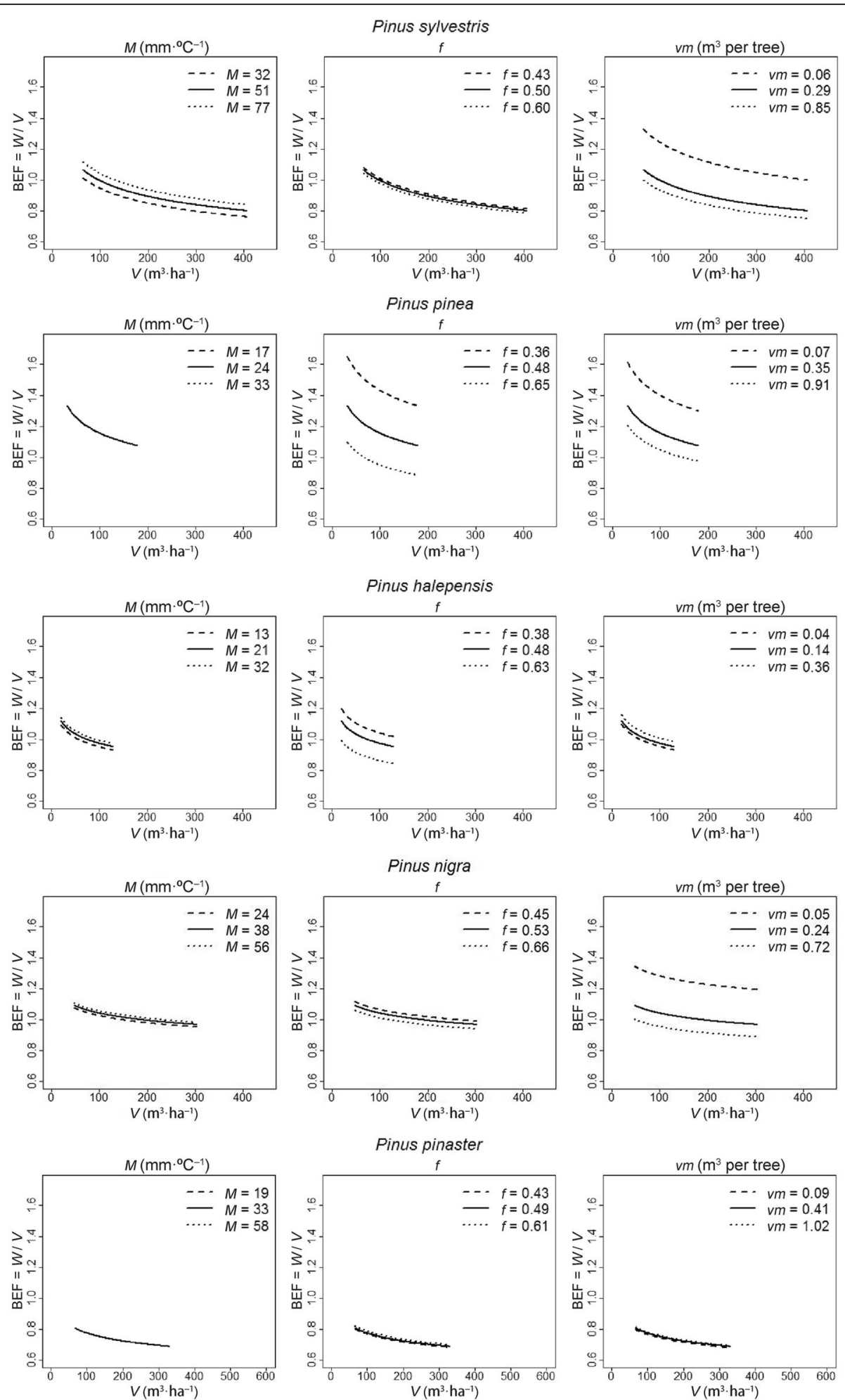

Fig. 3 Variation of biomass expansion factor (BEF), defined as dry weight biomass ( $W$, in $M g \cdot h a^{-1}$ ) estimated from the Total Model, divided by stand volume $\left(V\right.$, in $\left.\mathrm{m}^{3} \cdot h \mathrm{a}^{-1}\right)$, for different values of: Martonne aridity index $\left(M\right.$, in $\left.\mathrm{mm} \cdot{ }^{\circ} \mathrm{C}^{-1}\right)$; stand form factor $(f)$; and mean tree volume $(v m$, in $\mathrm{m}^{3}$ per tree). The lines are drawn within the inter-percentile 5\%-95\% range of stand volume distribution. Solid lines represent the mean value of the variable for each species and dashed and dotted lines represent the $5 \%$ percentiles, the mean $95 \%$ of the variable distribution for each species 

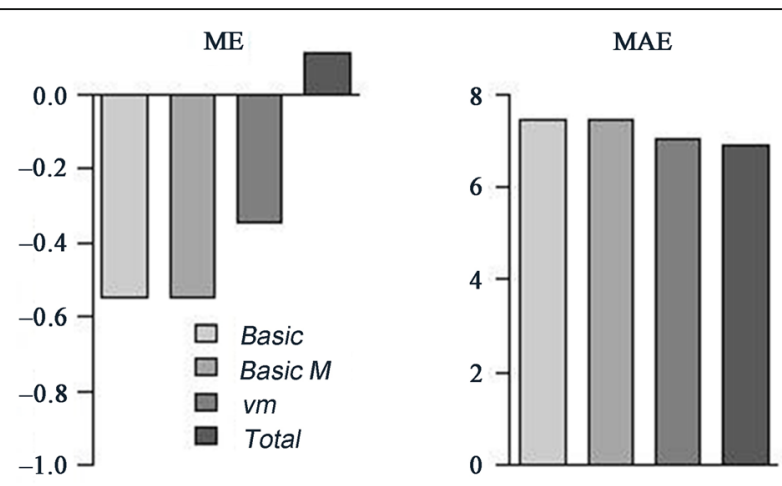

RMSE

MPE

MAPE
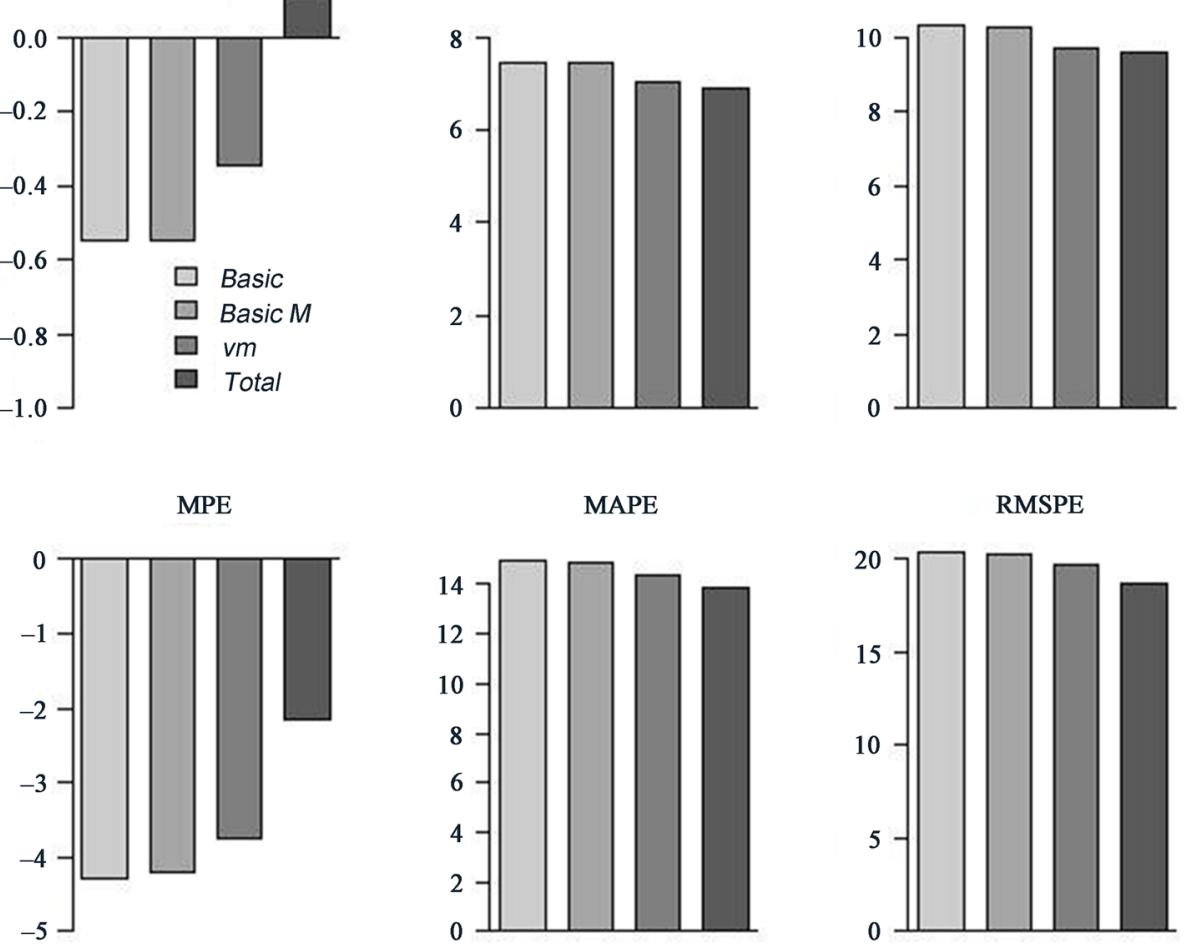

Fig. 4 Mean errors for carbon estimates at plot level for the studied pine species throughout peninsular Spain according the four studied models. ME, mean error (in Mg.ha ${ }^{-1}$ of C); MAE, mean absolute error (in Mg.ha ${ }^{-1}$ of C); RMSE, Root mean square error (in Mg.ha ${ }^{-1}$ of C); $M P E$, mean percentage error (in \%); MAPE, mean absolute percentage error (in \%); RMSE, Root mean square percentage error (in \%)

predictions for the studied pine species in the Iberian Peninsula was less than $20 \%$, which is slightly higher than $9 \mathrm{Mg} \cdot \mathrm{ha}^{-1}$ of $\mathrm{C}$. This Total Model resulted in an important reduction in the bias, reaching around $2 \%$.

\section{Discussion}

The use of BEFs to estimate biomass at stand level provides an interesting alternative for predicting biomass and carbon stocks in forest systems since stand volume $(V)$ is the only variable required. However, the use of traditional BEFs, mainly as constant values and generally obtained for stands under specific conditions, can result in biased biomass estimates if they are applied under different conditions (Di Cosmo et al. 2016). These biases can have a significant impact on estimated carbon in the tree layer when large-scale estimates are made, as is the case of national-scale predictions (Zhou et al. 2016). In this study, stand biomass models have been developed that include other easily obtained variables as independent variables, in addition to the stand volume. The fitted models allow us to update the carbon stocks in pine forests across mainland Spain for the five species studied using SNFI data. The strong relationship between stand biomass and stand volume (Fang et al. 1998) implies that the Basic Model can provide a good first estimate of biomass. This is confirmed by the results obtained as the
Basic Model yields good fit statistics. This suggests that, to a certain extent, the stand volume should absorb the effects of other variables, such as the stand age or stand density, as well as environmental conditions (Fang et al. 2001; Guo et al. 2010; Tang et al. 2016). Therefore, in the development of the different models, the structure of the Basic Model was maintained, expanding its coefficients so that if the specific coefficients corresponding to the effects of $M, v m$ and $f$ were not significant, the Basic Model is returned. However, the models improved for all species with the inclusion of the other variables (Tables 3 and 4), reflecting the fact that stands with the same volume can have different structures leading to different biomass. This is observed in the improvement achieved with the Total Model, both with regard to the goodness of fit of the model and the errors (Tables 3 and 4), indicating less biased and more accurate estimates when the stand characteristics and the aridity conditions $(M)$ are included.

The positive relationship found between the aridity index $M$ and the dry biomass $W$ for a given stand volume supports the findings presented by Aguirre et al. (2019), who reported higher productions in less arid conditions. This positive relationship between $M$ and $W$ suggests greater crown development and higher crown biomass for the same volume in less arid conditions. However, it is important to highlight that the individual 
tree biomass equations used did not consider this type of within-tree variation in the distribution of biomass with site conditions (Ruiz-Peinado et al. 2011). Hence, the observed effect of $M$ must be associated with changes in the stand structure. For example, the variation in $v m$ according to the aridity conditions, that is, the stand $V$ is distributed over more trees of smaller size or fewer larger trees according to the aridity of the site, since the proportion of crown biomass with respect to total biomass varies with tree size (Wirth et al. 2004; Menéndez-Miguélez et al. 2021). This would entail an interaction between the effect of $M$ and the effect of $v m$ in the models, as reflected in the case of Pn, which varies from negative in the basic model with $M$ to positive for the $v m$ Model and Total Model. However, in general, $M$ is not the most important variable to explain the variation in $W$ (Fig. $2 \mathrm{~b}$ ), as can also be observed in the small BEF variation for the studied species in relation with $M$ (Fig. 3).

The variable $v m$, as surrogate of the stand development stage, has a different influence on the models for $\mathrm{Ph}$ and Pt than for the rest of the species (Fig. 2c). The observed pattern for Ps, Pp and Pn indicates that the relationship between $W$ and $V$, or the BEF, decreases with $v m$, i.e. as the stage of stand development increases, as has been observed previously in other studies (Lehtonen et al. 2004; Teobaldelli et al. 2009). This behavior may be caused by differences in the relationship between the components of the trees. For example, Schepaschenko et al. (2018) observed an important decreasing effect of age on the branch and foliar biomass factors. Similarly, Menéndez-Miguélez et al. (2021) analyzed the patterns of crown biomass proportion with respect to total aboveground biomass of the tree as its size develops for the main forest tree species in Spain. These authors found that in the cases of Ps and Pp, this pattern was decreasing; while for Pn and Pt it was constant (the study did not include $\mathrm{Ph}$ ). These within-tree biomass distributions would validate the patterns found in the Ps, $\mathrm{Pp}$ and $\mathrm{Pt}$ models, but not the Pn model. However, Ph presents a totally different BEF behavior with the variation in $v m$. Analyzing the modular values of the different biomass fractions for this species presented in Montero et al. (2005), it can be observed that the proportion of crown biomass in this species increases slightly with the size of the tree, which could explain the opposite pattern observed in this species. However, this difference could also be due to the equations used to calculate the biomass (Ruiz-Peinado et al. 2011), since the maximum normal diameter of the biomass sample used in that study was $44 \mathrm{~cm}$, whereas for the Iberian Peninsula as a whole it was as much as $97 \mathrm{~cm}$ (Villanueva 2005). Schepaschenko et al. (2018) also reported that the number of branches in low productive, sparse forest is greater than in high productive, dense forests, which may be a cause for the increasing tendency of $W$ in $\mathrm{Ph}$ in relation to $v m$.
The results indicate an improvement in the models with the inclusion of the stand form factor, although the magnitude of the effect caused by this variable, as well as the improvement in the models, were greater for $\mathrm{Pp}$ and $\mathrm{Ph}$ than for the rest of the species (Fig. 2d, Table 3). To estimate the stand volume, diameter at breast height, total height of the tree and its shape are used, according to species and province available models (Villanueva 2005). However, to estimate stand biomass, the equations applied for the different tree components only depend on the species, the diameter at breast height and the total height of the tree, without considering the shape of the tree (Ruiz-Peinado et al. 2011). This difference explains the advisability of considering the stand form factor to avoid biases in the estimates, although it also highlights the need to study the dependence of the biomass equations on the different components of the tree according to their shape. In turn, this shape depends on genetic factors, environmental conditions, and stand structure (Cameron and Watson 1999; Brüchert and Gardiner 2006; Lines et al. 2012).

The models obtained underline the importance of considering the environmental conditions and the stand structure (size and shape of trees) when expanding the volume of the stand to biomass. If constant BEF values are used for all kinds of conditions, biomass may be underestimated in younger and less productive stands, while for more mature and/or productive stands it may be overestimated (Fang et al. 1998; Goodale et al. 2002; Yu et al. 2014). These authors also highlight the need to further our understanding of the influence of these factors on the individual tree biomass equations. In this regard, Forrester et al. (2017) found that the intraspecific variation in tree biomass depends on the climatic conditions and on the age and characteristics of the stand, such as basal area or density. The components that mostly depended on these variables were leaf and branch biomass, which suggests that it would be advantageous to have more precise equations for these tree components, which would therefore modify the stand biomass estimates. However, the inclusion of other variables in the tree biomass models in order to improve the accuracy would require a large number of destructive samples from trees under different conditions (site conditions, stand characteristics, age...), which would be difficult to obtain in most cases.

The suitability of SNFI data to develop models has been questioned by several authors (Álvarez-González et al. 2014; McCullagh et al. 2017). One of the main disadvantages is the lack of control about environmental conditions, stand age or history of the stand (Vilà et al. 2013; Condés et al. 2018; Pretzsch et al. 2019). Another shortcoming is the lack of differentiation of pine subspecies in the SNFI, like the two subspecies of Pn, salzmanii 
and nigra, or those of $\mathrm{Pt}$, atlantica and mesogeensis, which could lead to confusing results such as those obtained for Pt, which was the only species for which the Basic Model improved with the inclusion of both variables together, $v m$ and $f$. This could suggest that the relationship between volume and shape of trees differs according to the subspecies considered.

Through the models developed (Fig. 4), it is possible to provide more precise responses to the international requirements in terms of biomass and carbon stocks. Since the most recent SNFI, it has become possible to update the information at a required time. For this purpose, the least favourable situation was assumed, that is, that the only information available was that obtained from the most recent SNFI. However, the main limitation of the models developed is that they are only valid for a short time period, when the assumptions made can be assumed and when both climatic conditions and stand management do not vary (Peng 2000; Condés and McRoberts 2017). If the elapsed time would be too long for assuming that there is not mortality and that the stand form factor does not vary, the basic model could be applied. Furthermore, to achieve more precise updates, natural deaths and silvicultural fellings must be considered using scenario analysis or by estimating of past fellings (Tomter et al. 2016). Besides, a proper validation with independent data was not possible due to lack of such data. When the SNFI-4 is finished for all Spanish provinces, it would be interesting to validate the models developed.

\section{Conclusions}

The results reveal the importance of considering both, site conditions and stand development stage when developing stand biomass models. The inclusion of site conditions in the models for $\mathrm{Ps}, \mathrm{Ph}$ and $\mathrm{Pn}$, indicate that aridity conditions modulate the relationship between the dry weight biomass of a stand $(W)$ and its volume $(V)$, while for Pp and Pt this relationship was not influenced. As hypothesized, it was observed that for a lower aridity, the biomass weight and therefore that of carbon are higher for the same stand volume.

Besides, the results reveal the importance of considering both size and form of trees for estimating dry weight biomass, and therefore to estimate carbon stock. As expected, the relationship between dry weight biomass of the stand and its volume decreases when the stand development stage $(v m)$ increases, except for $\mathrm{Ph}$ whose behavior is the opposite, and $\mathrm{Pt}$ which is hardly affected by $v m$. However, the inclusion of this variable reduces the ME, MAE and RMSE for all the studied species, which indicates the importance of its consideration in the dry weight biomass estimation.

\section{Abbreviations}

NFI: National Forest Inventory; SNFI: Spanish National Forest Inventory; BEFs: Biomass expansion factors; Ps: Pinus sylvestris; Pp: Pinus pinea; Ph: Pinus halepensis; Pn: Pinus nigra; Pt: Pinus pinaster; $M$ : Martonne aridity index; vm: Mean tree volume; $W$ : Dry weight biomass; f: Stand form factor; C: Carbon weight

\section{In the subscripts}

$s p$ : Referred to the target species; T: Any time when no field data is available; I: Initial NFI survey; F: Final NFI survey

\section{Authors' contributions}

Condés, del Río, and Ruiz-Peinado developed the idea, Aguirre and Condés developed the models, Aguirre programmed the models, and all authors wrote the document. All authors critically participated in internal review rounds, read the final manuscript, and approved it.

\section{Funding}

This research received no specific grant from any funding agency in the public, commercial, or not-for-profit sectors.

\section{Availability of data and materials}

The raw datasets used and/or analyzed during the current study are available from Ministerio para la Transición Ecológica y el Reto Demográfico of the Government of Spain (https://www.mapa.gob.es/es/desarrollo-rural/ temas/politica-forestal/inventario-cartografia/inventario-forestal-nacional/ default.aspx).

\section{Declarations}

Ethics approval and consent to participate

Not applicable.

Consent for publication

Not applicable.

Competing interests

The authors declare that they have no competing interests.

\section{Author details}

${ }^{1}$ Department of Natural Systems and Resources, School of Forest Engineering and Natural Resources, Universidad Politécnica de Madrid, Madrid, Spain.

${ }^{2}$ INIA, Forest Research Center, Department of Forest Dynamics and

Management, Madrid, Spain. ${ }^{3}$ iuFOR, Sustainable Forest Management

Research Institute, University of Valladolid and INIA, Valladolid, Spain.

Received: 16 December 2020 Accepted: 20 April 2021

Published online: 14 May 2021

\section{References}

Achat DL, Fortin M, Landmann G, Ringeval B, Augusto L (2015) Forest soil carbon is threatened by intensive biomass harvesting. Sci Rep 5(1):15991. https://doi. org/10.1038/srep15991

Aguirre A, del Río M, Condés S (2018) Intra- and inter-specific variation of the maximum size-density relationship along an aridity gradient in Iberian pinewoods. Forest Ecol Manag 411:90-100. https://doi.org/10.1016/j.foreco.2 018.01.017

Aguirre A, del Río M, Condés S (2019) Productivity estimations for monospecific and mixed pine forests along the Iberian Peninsula aridity gradient. Forests 10(5):430. https://doi.org/10.3390/f10050430

Akaike $H$ (1974) A new look at the statistical model identification. In: Parzen E, Tanabe K, Kitagawa G (eds) Selected papers of Hirotugu Akaike. Springer series in statistics (perspectives in statistics). Springer, New York, pp 215-222. https://doi.org/10.1007/978-1-4612-1694-0_16

Alberdi I (2015) Metodología para la estimación de indicadores armonizados a partir de los inventarios forestales nacionales europeos con especial énfasis en la biodiversidad forestal. (Tesis Doctoral, Universidad Politécnica de Madrid). Madrid, España 
Alberdi I, Cañellas I, Vallejo R (2017) The Spanish National Forest Inventory: history, development, challenges and perspectives. Pesqui Florestal Bras 37(91):361-368. https://doi.org/10.4336/2017.pfb.37.91.1337

Alberdi I, Condés D, Millán J, Saura S, Sánchez G, Pérez F, Villanueva J, Vallejo R (2010) National forest inventories report, Spain (chapter 34). National forest inventories Pathways for common reporting, Springer, Berlin, pp 527-540

Alía R, García del Barrio J, Iglesias Sauce S, Mancha Núñez J, de Miguel y del Ángel J, Nicolás Peragón J, Pérez Martín F, de Ron DS (2009) Regiones de procedencia de especies forestales españolas. Organismo Autónomo Parques Nacionales, Madrid

Álvarez-González J, Cañellas I, Alberdi I, Gadow K, Ruiz-González A (2014) National Forest Inventory and forest observational studies in Spain: applications to forest modeling. Forest Ecol Manag 316:54-64. https://doi.org/10.1016/jforeco.2013.09.007

Barton K (2020) MuMln: Multi-Model Inference. R package version 1.43.17. https:// CRAN.R-project.org/package=MuMIn. Accessed 15 Jan 2021

Bravo-Oviedo A, Ruiz-Peinado R, Modrego P, Alonso R, Montero G (2015) Forest thinning impact on carbon stock and soil condition in southern European populations of $P$. sylvestris L. Forest Ecol Manag 357:259-267. https://doi. org/10.1016/j.foreco.2015.08.005

Breidenich C, Magraw D, Rowley A, Rubin JW (1998) The Kyoto protocol to the United Nations framework convention on climate change. Am J Int Law 92(2):315-331. https://doi.org/10.2307/2998044

Briggs JM, Knapp AK (1995) Interannual variability in primary production in tallgrass prairie: climate, soil moisture, topographic position, and fire as determinants of aboveground biomass. Am J Bot 82(8):1024-1030. https:// doi.org/10.1002/j.1537-2197.1995.tb11567.x

Brown S (2002) Measuring carbon in forests: current status and future challenges. Environ Pollut 116(3):363-372. https://doi.org/10.1016/S0269-7491(01)00212-3

Brüchert F, Gardiner B (2006) The effect of wind exposure on the tree aerial architecture and biomechanics of Sitka spruce (Picea sitchensis, Pinaceae). Am J Bot 93(10):1512-1521. https://doi.org/10.3732/ajb.93.10.1512

Cairns MA, Brown S, Helmer EH, Baumgardner GA (1997) Root biomass allocation in the world's upland forests. Oecologia 111(1):1-11. https://doi.org/10.1007/ s004420050201

Cameron A, Watson B (1999) Effect of nursing mixtures on stem form, crown size, branching habit and wood properties of Sitka spruce (Picea sitchensis (bong.) Carr.). Forest Ecol Manag 122(1-2):113-124. https://doi.org/10.1016/S0378-112 7(99)00036-5

Castedo-Dorado F, Gómez-García E, Diéguez-Aranda U, Barrio-Anta M, CrecenteCampo F (2012) Aboveground stand-level biomass estimation: a comparison of two methods for major forest species in Northwest Spain. Ann Forest Sci 69(6):735-746. https://doi.org/10.1007/s13595-012-0191-6

Condés S, Del Rio M, Sterba H (2013) Mixing effect on volume growth of Fagus sylvatica and Pinus sylvestris is modulated by stand density. Forest Ecol Manag 292:86-95. https://doi.org/10.1016/j.foreco.2012.12.013

Condés S, McRoberts RE (2017) Updating national forest inventory estimates of growing stock volume using hybrid inference. Forest Ecol Manag 400:48-57. https://doi.org/10.1016/j.foreco.2017.04.046

Condés S, Sterba H, Aguirre A, Bielak K, Bravo-Oviedo A, Coll L, Pach M, Pretzsch $H$, Vallet $P$, del Río M (2018) Estimation and uncertainty of the mixing effects on scots pine-European beech productivity from national forest inventories data. Forests 9(9):518. https://doi.org/10.3390/f9090518

Cox DR, Snell EJ (1989) The analysis of binary data, 2nd edn. Chapman and Hall, London

Dahlhausen J, Uhl E, Heym M, Biber P, Ventura M, Panzacchi P, Tonon G, Horváth T, Pretzsch H (2017) Stand density sensitive biomass functions for young oak trees at four different European sites. Trees 31(6):1811-1826. https://doi.org/1 0.1007/s00468-017-1586-7

Davidson EA, Janssens IA (2006) Temperature sensitivity of soil carbon decomposition and feedbacks to climate change. Nature 440(7081):165-173. https://doi.org/10.1038/nature04514

De Martonne E (1926) L'indice d'aridité. Bull Assoc Géographes Fr 3(9):3-5. https://doi.org/10.3406/bagf.1926.6321

del Río M, Barbeito I, Bravo-Oviedo A, Calama C, Cañellas I, Herrero C, Montero G, Moreno-Fernández D, Ruiz-Peinado R, Bravo F (2017) In: Bravo F, LeMay V, Jandl $R$ (eds) Managing forest ecosystems: the challenge of climate change. Managing Forest Ecosystems, vol 34. Springer, Cham, pp 301-327. https:// doi.org/10.1007/978-3-319-28250-3_15

Di Cosmo L, Gasparini P, Tabacchi G (2016) A national-scale, stand-level model to predict total above-ground tree biomass from growing stock volume. Forest Ecol Manag 361:269-276. https://doi.org/10.1016/j.foreco.2015.11.008
Eggleston S, Buendia L, Miwa K, Ngara T, Tanabe K (2006) IPCC guidelines for national greenhouse gas inventories. Institute for Global Environmental Strategies Hayama, Japan

Fang J, Chen A, Peng C, Zhao S, Ci L (2001) Changes in forest biomass carbon storage in China between 1949 and 1998. Science 292(5525):2320-2322. https://doi.org/10.1126/science.1058629

Fang J-Y, Wang GG, Liu G-H, Xu S-L (1998) Forest biomass of China: an estimate based on the biomass-volume relationship. Ecol Appl 8:1084-1091

Forrester DI, Tachauer IHH, Annighoefer P, Barbeito I, Pretzsch H, Ruiz-Peinado R, Sileshi GW (2017) Generalized biomass and leaf area allometric equations for European tree species incorporating stand structure, tree age and climate. Forest Ecology and Management 396:160-175

Führer E, Horváth L, Jagodics A, Machon A, Szabados I (2011) Application of a new aridity index in Hungarian forestry practice. Időjárás 115:205-216

Global Forest Resources Assessment (2020) Main report. Rome

Gonzalo Jiménez J (2010) Diagnosis fitoclimática de la España peninsular. Hacia un modelo de clasificación funcional de la vegetación y de los ecosistemas peninsulares españoles. Organismo Autónomo de Parques Nacionales (MARM), Madrid

Goodale CL, Apps MJ, Birdsey RA, Field CB, Heath LS, Houghton RA, Jenkins JC, Kohlmaier GH, Kurz W, Liu S, Nabuurs G-J, Nilsson S, Shvidenko AZ (2002) Forest carbon sinks in the northern hemisphere. Ecol Appl 12(3):891-899. https://doi.org/10.1890/1051-0761(2002)012[0891:FCSITN]2.0.CO;2

Guo Z, Fang J, Pan Y, Birdsey R (2010) Inventory-based estimates of forest biomass carbon stocks in China: a comparison of three methods. Forest Ecol Manag 259(7):1225-1231. https://doi.org/10.1016/j.foreco.2009.09.047

Houghton JT, Meiro Filho L, Callander BA, Harris N, Kattenburg A, Maskell K (1996) Climate change 1995: the science of climate change. Cambridge University Press, Cambridge

Houghton R, Hall F, Goetz SJ (2009) Importance of biomass in the global carbon cycle. J Geophy Res Biogeo 114:G00E03

Ibáñez J, Vayreda J, Gracia C (2002) Metodología complementaria al Inventario Forestal Nacional en Catalunya. El Inventario Forestal Nacional: elemento clave para la Gestión Forestal Sostenible. Fundación General de la Universidad de Valladolid, Valladolid, pp 67-77

Jagodziński AM, Dyderski MK, Horodecki P (2020) Differences in biomass production and carbon sequestration between highland and lowland stands of Picea abies (L.) H. Karst. and Fagus sy/vatica L. Forest Ecol Manag 474: 118329. https://doi.org/10.1016/j.foreco.2020.118329

Jagodziński AM, Zasada M, Bronisz K, Bronisz A, Bijak S (2017) Biomass conversion and expansion factors for a chronosequence of young naturally regenerated silver birch (Betula pendula Roth) stands growing on post-agricultural sites. Forest Ecol Manag 384:208-220. https://doi. org/10.1016/j.foreco.2016.10.051

Jalkanen A, Mäkipää R, Ståhl G, Lehtonen A, Petersson H (2005) Estimation of the biomass stock of trees in Sweden: comparison of biomass equations and age-dependent biomass expansion factors. Ann For Sci 62(8):845-851. https://doi.org/10.1051/forest:2005075

James J, Harrison R (2016) The effect of harvest on forest soil carbon: a metaanalysis. Forests 7(12):308. https://doi.org/10.3390/f7120308

Kassa A, Konrad H, Geburek T (2017) Landscape genetic structure of Olea europaea subsp. cuspidata in Ethiopian highland forest fragments. Conserva Genet 18(6):1463-1474. https://doi.org/10.1007/s10592-017-0993-z

Kollmann FFP (1959) Tecnología de la madera y sus aplicaciones. Ministerio de Agricultura, Madrid

Lehtonen A, Cienciala E, Tatarinov F, Mäkipää R (2007) Uncertainty estimation of biomass expansion factors for Norway spruce in the Czech Republic. Ann Forest Sci 64(2):133-140. https://doi.org/10.1051/forest:2006097

Lehtonen A, Mäkipää R, Heikkinen J, Sievänen R, Liski J (2004) Biomass expansion factors (BEFs) for scots pine, Norway spruce and birch according to stand age for boreal forests. Forest Ecol Manag 188(1-3):211-224. https://doi.org/1 0.1016/j.foreco.2003.07.008

Lines ER, Zavala MA, Purves DW, Coomes DA (2012) Predictable changes in aboveground allometry of trees along gradients of temperature, aridity and competition. Glob Ecol Biogeogr 21(10):1017-1028. https://doi.org/10.1111/ j.1466-8238.2011.00746.x

Magee $L$ (1990) $R^{2}$ measures based on Wald and likelihood ratio joint significance tests. Am Stat 44:250-253

Mäkipää R, Lehtonen A, Peltoniemi M (2008) Forest inventories as a source of information for assessment of carbon. In: Dolman $H$, Valentini R, Freibauer A (eds) The continental-scale greenhouse gas balance of Europe (ecological studies). Springer, New York, pp 192-195 
Martin GL (1982) A method for estimating ingrowth on permanent horizontal sample points. For Sci 28:110-114

McCullagh A, Black K, Nieuwenhuis M (2017) Evaluation of tree and stand-level growth models using national forest inventory data. Eur J Forest Res 136(2): 251-258. https://doi.org/10.1007/s10342-017-1025-8

McRoberts RE, Tomppo EO (2007) Remote sensing support for national forest inventories. Remote Sens Environ 110(4):412-419. https://doi.org/10.1016/j. rse.2006.09.034

Menéndez-Miguélez M, Ruiz-Peinado R, del Río M, Calama R (2021) Improving tree biomass models through crown ratio patterns and incomplete data sources. Eur J Forest Res. https://doi.org/10.1007/s10342-021-01354-3

Montero G, Ruiz-Peinado R, Muñoz M (2005) Producción de biomasa y fijación de $\mathrm{CO}_{2}$ por los bosques españoles. INIA-Instituto Nacional de Investigación y Tecnología Agraria y Alimentaria, Madrid

Montero G, Serrada R (2013) La situación de los bosques y el sector forestal en España - ISFE 2013. Sociedad Española de Ciencias Forestales, Lourizán (Pontevedra)

Nagelkerke NJD (1991) A note on a general definition of the coefficient of determination. Biometrika 78(3):691-692. https://doi.org/10.1093/biomet/78.3. 691

Neumann M, Moreno A, Mues V, Härkönen S, Mura M, Bouriaud O, Lang M, Achten WM, Thivolle-Cazat A, Bronisz K, Merganič J, Decuyper M, Alberdi I, Astrup R, Mohren F, Hasenauer H (2016) Comparison of carbon estimation methods for European forests. Forest Ecol Manag 361:397-420. https://doi. org/10.1016/j.foreco.2015.11.016

Peichl M, Arain MA (2007) Allometry and partitioning of above- and belowground tree biomass in an age-sequence of white pine forests. Forest Ecol Manag 253(1-3):68-80. https://doi.org/10.1016/j.foreco.2007.07.003

Peng C (2000) Growth and yield models for uneven-aged stands: past, present and future. Forest Ecol Manag 132(2-3):259-279. https://doi.org/10.1016/S03 78-1127(99)00229-7

Penman J, Gytarsky M, Hiraishi T, Krug T, Kruger D, Pipatti R, Buendia L, Miwa K, Ngara T, Tanabe K, Wagner F (2003) Good practice guidance for land use, land-use change and forestry. The Institute for Global Environmental Strategies (IGES) for the IPCC, Hayama, Kanagawa

Petersson H, Holm S, Ståhl G, Alger D, Fridman J, Lehtonen A, Lundström A Mäkipää R (2012) Individual tree biomass equations or biomass expansion factors for assessment of carbon stock changes in living biomass-a comparative study. Forest Ecol Manag 270:78-84. https://doi.org/10.1016/j. foreco.2012.01.004

Pinheiro J, Bates D, DebRoy S, Sarkar D, Heisterkamp S, Van Willigen B, Maintainer R (2017) Package 'nlme'. Linear and Nonlinear Mixed Effects Models, version 3.1. https://cran.r-project.org/. Accessed 15 Jan 2021

Pretzsch H, del Río M, Biber P, Arcangeli C, Bielak K, Brang P, Dudzinska M, Forrester DI, Klädtke J, Kohnle U, Ledermann T, Matthews R, Nagel J, Nagel R, Nilsson U, Ningre F, Nord-Larsen T, Wernsdorfer H, Sycheva E (2019) Maintenance of long-term experiments for unique insights into forest growth dynamics and trends: review and perspectives. Eur J Forest Res 138(1):165-185. https://doi.org/10.1007/s10342-018-1151-y

Ruiz-Peinado R, Bravo-Oviedo A, López-Senespleda E, Montero G, Río M (2013) Do thinnings influence biomass and soil carbon stocks in Mediterranean maritime pinewoods? Eur J Forest Res 132(2):253-262. https://doi.org/10.1 007/s10342-012-0672-z

Ruiz-Peinado R, del Río M, Montero G (2011) New models for estimating the carbon sink capacity of Spanish softwood species. Forest Syst 20(1):176-188. https://doi.org/10.5424/fs/2011201-11643

Schepaschenko D, Moltchanova E, Shvidenko A, Blyshchyk V, Dmitriev E, Martynenko O, See L, Kraxner F (2018) Improved estimates of biomass expansion factors for Russian forests. Forests 9(6):312. https://doi.org/10.3390/ f9060312

Shortt JS, Burkhart HE (1996) A comparison of loblolly pine plantation growth and yield models for inventory updating. South J Appl For 20(1):15-22. https://doi.org/10.1093/sjaf/20.1.15

Soares P, Tomé M (2004) Analysis of the effectiveness of biomass expansion factors to estimate stand biomass. Proceedings of the International Conference on Modeling Forest Production, 19-22 April, Austria, pp 368-374

State of Europe's Forests (2015) Europe's Status \& Trends in Sustainable Forest Management in Europe

Stegen JC, Swenson NG, Enquist BJ, White EP, Phillips OL, Jørgensen PM, Weiser MD, Monteagudo Mendoza A, Núñez Vargas P (2011) Variation in above- ground forest biomass across broad climatic gradients. Glob Ecol Biogeogr 20(5):744-754. https://doi.org/10.1111/j.1466-8238.2010.00645.x

Tang X, Fehrmann L, Guan F, Forrester DI, Guisasola R, Kleinn C (2016) Inventorybased estimation of forest biomass in Shitai County, China: a comparison of five methods. Ann For Res 59:269-280

Team RC (2014) R: A language and environment for statistical computing. R foundation for statistical computing, Vienna http://www.R-project.org/. Accessed 15 Jan 2021

Teobaldelli M, Somogyi Z, Migliavacca M, Usoltsev VA (2009) Generalized functions of biomass expansion factors for conifers and broadleaved by stand age, growing stock and site index. Forest Ecol Manag 257(3):10041013. https://doi.org/10.1016/j.foreco.2008.11.002

Tobin B, Nieuwenhuis M (2007) Biomass expansion factors for Sitka spruce (Picea sitchensis (bong.) Carr.) in Ireland. Eur J Forest Res 126(2):189-196. https://doi. org/10.1007/s10342-005-0105-3

Tomppo E, Gschwantner T, Lawrence M, McRoberts RE (2010) National forest inventories: pathways for common reporting. Springer, Netherlands, pp 541553. https://doi.org/10.1007/978-90-481-3233-1

Tomter SM, Kuliešis A, Gschwantner T (2016) Annual volume increment of the European forests - description and evaluation of the national methods used. Ann Forest Sci 73(4):849-856. https://doi.org/10.1007/s13595-016-0557-2

Vicente-Serrano SM, Cuadrat-Prats JM, Romo A (2006) Aridity influence on vegetation patterns in the middle Ebro Valley (Spain): evaluation by means of AVHRR images and climate interpolation techniques. J Arid Environ 66(2): 353-375. https://doi.org/10.1016/j.jaridenv.2005.10.021

Vilà M, Carrillo-Gavilán A, Vayreda J, Bugmann H, Fridman J, Grodzki W, Haase J, Kunstler G, Schelhaas M, Trasobares A (2013) Disentangling biodiversity and climatic determinants of wood production. PLoS One 8(2):e53530. https://doi. org/10.1371/journal.pone.0053530

Villanueva J (2005) Tercer inventario forestal nacional (1997-2007). Ministerio de Medio Ambiente, Madrid

Wirth C, Schumacher J, Schulze E-D (2004) Generic biomass functions for Norway spruce in Central Europe-a meta-analysis approach toward prediction and uncertainty estimation. Tree Physiol 24(2):121-139. https://doi.org/10.1093/ treephys/24.2.121

Yu D, Wang X, Yin Y, Zhan J, Lewis BJ, Tian J, Bao Y, Zhou W, Zhou L, Dai L (2014) Estimates of forest biomass carbon storage in Liaoning Province of Northeast China: a review and assessment. PLoS One 9(2):e89572. https://doi. org/10.1371/journal.pone.0089572

Zhou X, Lei X, Peng C, Wang W, Zhou C, Liu C, Liu Z (2016) Correcting the overestimate of forest biomass carbon on the national scale. Method Ecol Evol 7(4):447-455. https://doi.org/10.1111/2041-210X.12505

\section{Submit your manuscript to a SpringerOpen ${ }^{\circ}$ journal and benefit from:}

- Convenient online submission

- Rigorous peer review

- Open access: articles freely available online

- High visibility within the field

- Retaining the copyright to your article

Submit your next manuscript at $>$ springeropen.com 